\title{
A Toddler at 60? Nigerian's Democracy and Development under Arabic Poetic Loupe
}

\author{
Saheed .0. Timehin* \\ Department of Foreign Languages, Lagos State University, Lagos, Nigeria. \\ *Correspondence: saheedot@yahoo.com (Saheed . O. Timehin, Ph. D, Department of Foreign Languages, Lagos \\ State University, Lagos, Nigeria).
}

\begin{abstract}
When, in 1960, Nigeria was granted independence from colonial rule, it was thought that the country was going to be a model of a brilliant experience in parliamentary democracy; but less than six years after the supposed license for self-rule, a military coup struck which lay to rest the dreams of most people. From that coup, the nation has gone through a civil war and several upheavals of varying dimensions while its potentials have nosedived and its people, despite the immense human and natural resources of the country, barely live above the poverty line. This sad situation has, for years, attracted several reactions from people of different social classes. One class that has often been ignored in the Nigerian socio-political conversation is the ever-growing horde of Arabic verse-smiths that use the Arabic language as their medium of registering their reactions to national challenges. Using Shaykh Ma'ruf Ahmad al-Ajahwi as a representational model, this study examines Shaykh's poem "Naijīiriyya fi ām al sittīn" (Nigeria at Sixty); it places his thoughts and sentiments within the general matrix of Nigerian socio-political discourse and posits that the poem indeed represents the true yearnings of the average Nigerian who daily suffers owing to bad policies of the government. It goes further to reflect on the challenge of democracy and development in their global context as well as the particularistic expressions of both concepts in a developing country like Nigeria and opines that the average Nigerian is more concerned about good governance and not necessarily the nomenclature given to a system of government.
\end{abstract}

Keywords: Social realism, Democracy, Arabic poetic loup, Sustainable development, and Insecurity.

\section{INTRODUCTION:}

There is no disagreement on the fact that all is not well with the geo-political entity called Nigeria. It is also not unknown that since its independence in 1960, achieving positive growth and sustainable development has become her major challenge. Happenings in the last two decades in particular have shown that the nation has been one of the most unsettled and most backward human societies in the world while majority of its citizen are arguably among the poorest, unhappy and unfulfilled people in the contemporary world despite its immense human and material resources, its magnificent leg- acy, and its incomparably vibrant ethno-cultural diversity. It is bedevilled by communal militias warring among themselves and in conflict with other ethnic nationalities; incapable of feeding themselves, providing security for themselves and indeed, governing themselves. The accommodative ethno-cultural system they inherited has been distorted into sick exclusivist reasoning resulting in chauvinistic and antagonistic orientations that can neither hold together the internal structure of the groups that uphold them nor engage effectively the groups that are different from them. Political leaders, religious clerics, media practitioners, and social thinkers have all 
responded to the challenge in different ways. One group of unsung stakeholders is the ever-increasing army of Arabic verse-smiths that have taken social realism as their forte and have responded to virtually every challenge the nation faces in accordance with their peculiar circumstances and how these challenges have impacted upon them. One of the most outstanding voices in this horde of Arabic bards is al-Shaykh Ma'ruf Akanni Mustafa Ahmad al Ajahwi, the founder of "al-Ma'rifah al Islamiyyah Foundation, Lekki Peninsula,Ajah in the Eti-Osa Local Government Area of Lagos State, Nigeria. Born in the early seventies to Mallam Mustafa Ashamu-Oladejo at OkeOlola in the Atiba area of Oyo town, the ancient capital of the Yoruba Kingdom, Ma'ruf had his elementary, intermediate and seconddary Arabic and Islamic education in Ibadullah Islamic School under the tutelage and mentorship of the founder of the citadel of learning, Shaykh Yusuf Adewuyi, where he excelled at every level of his education and graduating as the overall best student. $\mathrm{He}$ is till today the President of the school's alumni association. He later got admission to pursue further studies at the Institute of Islamic Legal Studies, Mauritania, and an affiliate of Muhammad bnSa'ud University, Saudi Arabia. On returning to Nigeria, he established his school, Mu'assasah al-Ma'rifah al Islamiyyah at Lekki in the Eti-Osa local government area of Lagos in year 2000, and the school has, since its inception, produced outstanding scholars, clerics, preachers and proprietors of Arabic and Islamic training centres. Shaykh Ma'ruf Ahmad is a gifted orator, writer and verse-smith whose prose works are mainly school texts that simplify specific subjects for learners of Arabic and Islamic studies, he has published two major Diwans (anthologies) titled, 'al Jawharah' and 'al I'lām bi Manāqib al A'lām'. A cursory glance at the contents of his anthologies reveals that social realism is a core motif for his poetry. $\mathrm{He}$ responds to so many social challenges in his poetry and goes beyond the traditional themes that are common among the Nigerian poets of the Arabic language.

In 2020, several Nigerian Arabic verse smiths from different parts of the country composed poems in which they lamented the plight of the nation as it celebrated her $60^{\text {th }}$ independence anniversary. These poems, mostly written in elegiac tone, reveal the shared experiences of their writers. While the styles and diction differ, the theme, mood and imagery cohere; and among the most outstanding of these poets is Ma'ruf Ahmad who's "Naijiriya fi 'ām al sittīn" (Nigeria at 60) appears to be one the most faithful representations of the contemporary Nigerian experience. Written in classical Arabic devoid of verbose diction, the poem is a 37 stanza ode composed on the Kămil metre.

The poet decries the Nigerian situation by addressing the nation directly querying her for the gloom that characterised her mood on her anniversary. He raises a number of questions trying to figure out the reason for the sad mien of the nation and seems to sigh with a sneer that she actually deserves no celebration as her security, stability and development record is deplorable. He says:

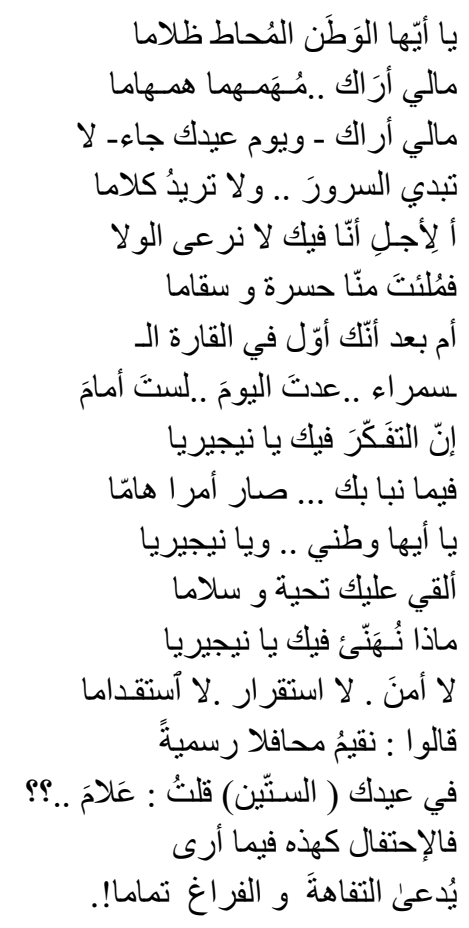

1). O Motherland engulfed in darkness, why do I see you murmuring strongly?

2). I see that, on your anniversary, you did not express any delight and neither did you utter a word?

$3)$. Is it because we are unpatriotic that you grew sad and sick of us?

4). Or because you no longer lead Africa as you used to?

5). Indeed, O Nigeria, thinking about your predicament has become mind-boggling.

6). O my Motherland, O Nigeria, I extend to you my greetings of peace.

7). What do we felicitate with you for, O Nigeria?

No security, no stability and no development. 
8). It was proposed that we should hold official ceremonies to mark your $60^{\text {th }}$, anniversary but I queried: for what?

9). A celebration such as this to me is better called a trifle and waste of time.

The above verses sum up the sentiments of the average Nigerian. Since independence, the nation has experienced a myriad of conflicts that have continuously challenged peace and harmony within its borders. These conflicts have, in the last three decades, transformed into serious security challenges which range from kidnapping, suicide attacks, bombings, ritual killings, assassinations, brigandage, banditry and armed robbery, and have not only destroyed lives and properties, but also blacklisted Nigeria as a safe haven for local and foreign investments (Majekodunmi, 2012). The level of insecurity in the country has truly affected its economic development. While insecurity is generally seen as a state of absence of peace, safety, certainty or confidence, its semantic tenor in the Nigerian reality has a cosmopolitan complexity that is crosscutting and multi-dimensional. In order to properly deconstruct the slippery epistemological terrains of the Nigerian usage of the term, we should under-stand how comprehensive the insecurity to which Nigerians are exposed is. In the country, insecurity is not just a state of being subject to danger, exposed to risk or anxiety. It is, as Achumba and others opine, an experience that covers both the physical and mental essence of a person. In other words, a person is said to be secured when not exposed to any form of danger or risk of physical or moral aggression, accident, theft or deterioration (Achumba et al., 2013).

According to Frances Stewart, there are deep connections between development and the states of security or insecurity. He argues that these connections affect three horizons namely:

The immediate impact of security/insecurity on well-being and consequently development achievements (or the ways in which security forms part of the definition of development) - i.e., security's role as part of our objectives.

The way that insecurity affects (non-security) elements of development and economic growth, or the security instrumental role.

The way development affects security, or the development instrumental role.
Understood as such, security issues should therefore become a part of development policy formulations in so far as they create enabling environment for growth and development. In a similar vein, development issues will also surface at the level of security policy formulations because enhanced development increases human security (Stewart, 2004; Alam et al., 2021).

According to Eme \& Anthony, the impact of insecurity in Nigeria includes:

i). Social dislocation and population displacement

ii). Social tensions and new pattern of settlements which encourages Muslims/Christians or members of an ethnic group moving to familiar enclaves.

iii). Heightened citizenship question and encourages hostility between "indigenes" and "settlers".

iv). Dislocation and disruption of family and communal life.

v). General atmosphere of mistrust, fear, anxiety and frenzy

vi). Dehumanization of women, children, and men especially in areas where rape, child abuse and neglect are used as instruments of war.

vii). Deepening of hunger and poverty in the polity

viii). Atmosphere of political insecurity and instability including declining confidence in the political leadership and apprehension about the system.

ix). Governance deficit as a result of security agencies inefficiency and corruption.

x). Loss of man hours due to shortened working hours by banks and commercial institutions and the unprecedented loss of man hours or closure of businesses by those who work at night due to the curfew consequent on the declaration of state of emergency on some states. This has affected not only the formal sector but also the informal but widespread sector such as the local suya (beef barbecue) spots, food canteens and street vendors and viewing centers (Dabak, 2014).

The poet also reflects on the ills in the Nigerian society and castigates the rulers as the causes of these ills. He says interalia:

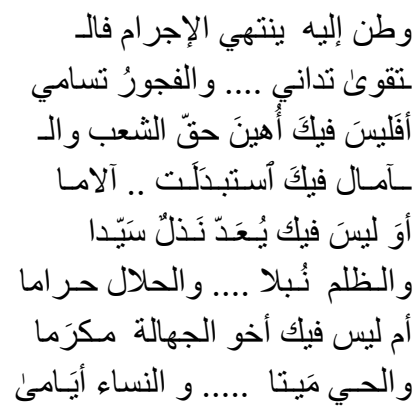




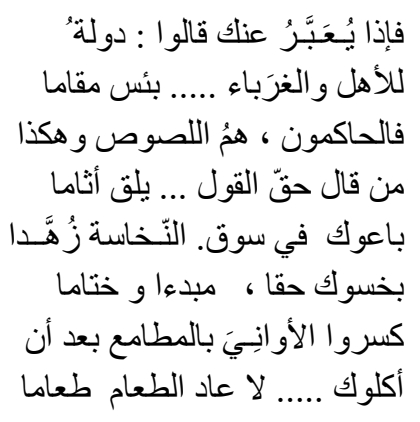

10). A country where criminality is rampant, piety is low, while immorality is a thing of pride.

11). Is it not within your borders that the rights of your people are compromised and hopes are turned to pains?

12). Is it not within you that a rogue is regarded a leader?

Where injustice is nobility and lawful things are forbidden?

13. Is it not within you that the ignorant is honoured; and the living becomes dead and women become widows?

14). When you are spoken about, it is said: what a bad habitat for citizen and non-citizen alike!

15). The rulers are indeed the thieves, and whoever speaks the truth commits a crime.

16). They sold you off in the slave market...Cheaply they sold you from beginning to end.

17). With greed they broke the containers after they have devoured you, until nothing is left of the meal.

He then goes ahead to propose a rather radical solution which is to sacrifice the political leaders as ransoms for the nation! Despite his pacifist stance on so many social issues, he appears to have been radicalised by the happenings in the nation to an extent that he would propose the elimination of the political leaders. This also underscores the notion of extreme frustration leading to aggressive behaviour (Rummel, 1977). He declares:

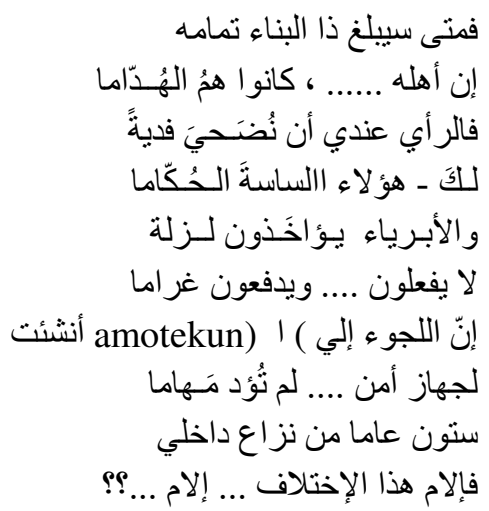

18). When will the structure reach its completion?
Surely, its people are its destroyers.

19). My opinion is that we sacrifice these leaders as ransom to you.

20). The Innocents are arrested for crimes they did not commit, yet they pay a fine.

21). Resorting to the establishment of Amotekun (an ethno-cultural security outfit created by political leaders in South West Nigeria) as a security organ cannot fulfil the task.

22). 60 years of internal conflicts; till when will this last? Till when?

The poet wonders how the construction of the nation can be completed since Nigerians themselves are the destroyers. Indeed, the steady sabotage of all efforts at reconstructing the nation is the result of several factors which include the absence of social justice in the country, widespread illiteracy, political corruption, and the commercialization of religion by the institutional representatives of God themselves, all of which have combined to further deepen the divides between the various groups in Nigeria there-by resulting in the use of ethnic militias as the executors of political agenda and causing terrible security threats. This sad situation gave birth to serious doubts about whether democracy as a system of governance has the wherewithal to tame the 'wildness' of developing and underdeveloped societies in the modern world. The civil and 'humane' atmosphere of the democratic dispensation without the 'iron hand' of the military regimes is thus believed to have created the immoral corporate practices that ultimately led to nepotism and unhealthy rivalry among the people; and religion, which is supposed to be the custodian of ethical values, became the justifier of several corrupt practices, or the sanctifying authority for the cults of impunity that sprang up as a result of the government's unwillingness or the absence of institutional capacity to arrest the situation (Salawu, 2010).

Among the debated issues in recent years among economists and social theorists is whether there is a link between democracy and development or not. Scholars like Pel, Campos and Jamo are of the opinion that there is causal link between democracy and development because democracy facilitates free human choice and allows for wider political participation which ultimately creates the drive for development (Jamo, 2013). Other scholars however differ in this regard. They maintain that democracy does 
not necessarily lead to development and they cite for example, the experiences of Korea, Taiwan, or Indonesia which show that a strong purpose-driven authoritarian state is better able to engineer a successful process of economic development than an electoral democracy which in most cases is unable to discipline arrant pressure groups and erring legislators that seek to slow down the development process (Jamo, 2013). It is in fact this natural tendency of a democratic system to fragment, diffuse, and divide power among many different stakeholders at many different levels, both within the state and among societal actors, thereby making decision-making processes more time-consuming, that has led many other analysts in academic and policy circles alike to argue that, in the developing world, authoritarian regimes may be better suited than democratic ones to promote economic development. As Halperin and others have noted, 'the appeal of the authoritarianled approach has ... at least something to do with its expediency, in comparison to the messy and timeconsuming procedures typical of democracy'. The core of this argument is that development requires a strong, centralised, highly autonomous government, especially when poor countries need to play 'catchup', and that democratic politics are simply too messy and unpredictable to provide such a structure (Alina, 2007).

The poet goes ahead to ridicule the growth of the nation detailing a list of woes that have become the omnipresent Nigerian reality. He argues that a nation that cannot stand on its feet at the age of sixty is nothing but a child among nations. He alludes to the failure of govern-mental policies in ensuring good life for the citizenry citing the failed parental hopes in children, poor infrastructure, unemployment, and political corruption as examples of the daily experiences of Nigerian. He says:

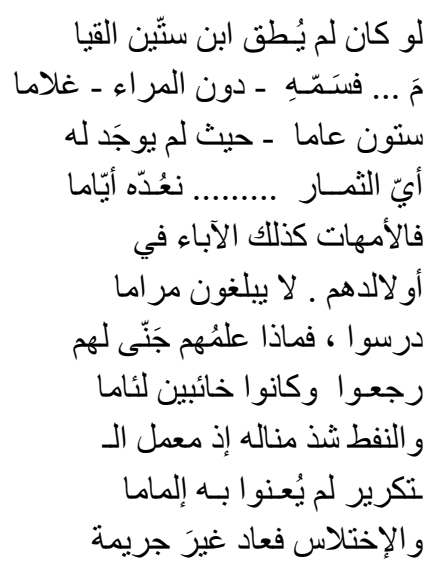

UniversePG I www.universepg.com

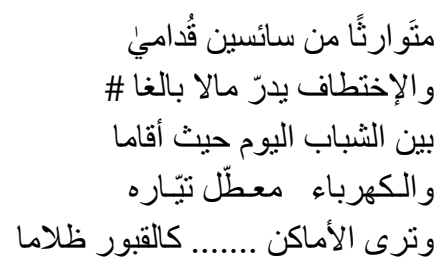

23). If sixty years old is unable to stand, you should, without doubt, call him a kid.

24). Sixty years with no fruit we can reckon as gain.

25). The mothers and fathers alike see not their desired aspiration for their children in them.

26). Though they are educated, what has their knowledge earned them? They returned disappointed, reproached.

27). Petroleum became unattainable because the building refinery is not given due attention.

28). Embezzlement of fund is no longer a crime- a trait inherited from political forbears.

29). Kidnapping became a profitable venture among the youth wherever they are.

30). And the supply of electricity is ever unstable, while you see everywhere covered in darkness like graves.

The poet, after lamenting the situation, turns to religious clerics to pray for the nation. To him, the situation is almost hopeless without Divine intervention. His appeal also shows that he does not subscribe to religious exclusivism. This is because unlike exclusivists, he believes that Christian prayers are also accepted by God and therefore calls upon Christian clerics to also pray for the nation. He argues that he could see what gifted soothsayers and clairvoyants do not see-that Nigeria is at a precipice of war. He says:

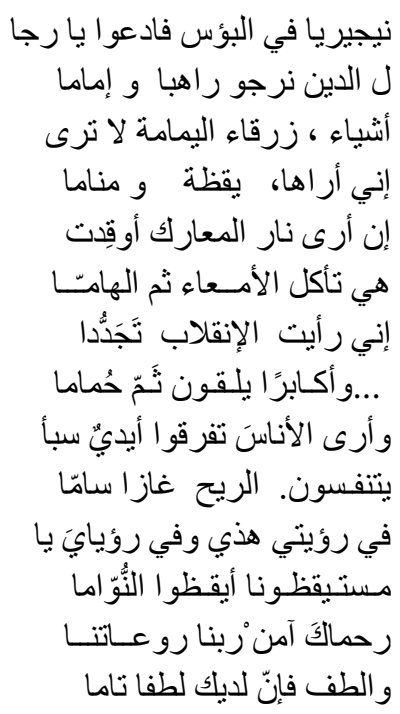

31). Nigeria is in misery, pray, o men of faith, we request every pastor and Imam to partake in it. 
32). Things that Zarqā al Yamāmah cannot see, I see them in a state of wakefulness and while a sleep.

33). I see fire of wars kindled, it eats the intestine, Then the major parts.

34). I see revolution rejuvenated, the great ones meet their end, likewise the weak.

35). I see men separated, they breathe in poisonous gas.

36). This is what I envision and it is in my vision.

$O$ ye! Who wakes us up, wake those asleep.

37). Your mercy, O Lord! Our magnificent God,

Be merciful, surely, complete mercy rests with you.

It is perhaps pertinent, beyond the poet's lamentation, to reflect on the Nigerian situation in light of the concerns being expressed by many Nigerians that military regimes are more effective than democratic systems. Though they know that most of the problems the nation faces were created by military regimes, they are also aware that the best experience of good governance they ever had was also under the Muritala Muhammed led military regime which was a very short one. Chan, in her 2009 study, "Democracy and Development in Japan and some Asian newly industrialized Countries" examined whether developing countries need to adopt democracy or any western model to achieve economic success. She posits that economic and social freedoms are necessary, but not western liberal democracy and its appurtenances. She insists that liberal democracy is not a prerequisite to development and that any system that guarantees social and economic rights can drive development. To her, development can be achieved irrespective of the type of political system or structure as long as social and economic freedoms are available. This view is also consistent with the opinions of Sirowy and Linkels, Bardhan, Przeworski and Lamongi (Jamo, 2013).

In fact, some studies seem to advocate that a benevolent autocracy should first develop the nation by instilling the discipline of development in the citizenry before democracy is established to build upon it. Anna Lekval in her work, 'Development First, Democracy Later?'; Stephanie Olk in her thought provoking study, 'The Relationship between Economic Development and Democracy in Africa' and Liang-Chih Evans Chen in the celebrated article, 'Development First, Democracy Later or Democracy First and Development Later-The Controversy over Development and Democracy, have all examined various aspects of this thesis. Akin to this is the fact that leading political figures are beginning to revisit their mythical views about democracy and its exponents. A leading politician in the US, Jerry Fresia, observes: 'Far from being a government of 'the people', ours is a government which rests on the assumption that 'the people', especially when they become politically excited, interested, and alive are thought of as subversive. Any serious student of political surveillance and repression in this country knows this to be true. But we seem to prefer to protect our moral high-mindedness by permitting elites, virtually at every chance they get, to persist in the lie that it is 'we the people', and not 'we the largest property owners', who govern this country. In so doing, we risk weakening our understanding of the ways, which systematically subordinate our lives to the interests of the rich and politically powerful, and in so doing; we invite our own destruction (Fresia, 1998). Similarly, Ralph Epperson also declares: 'It is generally conceded that even a monarchy or a dictatorship is an oligarchy, or a government run by a small, ruling minority. Such is also the case with a democracy, for this form of government is traditionally controlled at the top by a small ruling oligarchy. The people in a democracy are conditioned to believe that they are indeed the decision-making power of government, but in truth there is almost always a small circle at the top making the decision for the entirety' (Epperson, 1985). Like other Nations of the world, Nigerians too see democracy as the best option yet their tales of woe under so called "democratic dispensations" compete with their lamentations under the military. The ways in which the nation has been held to ransom by corrupt politicians and the perceived helplessness of the nation in battling them despite the shocking revelations of the magnitude of their corrupt ways, show that the country lack the institutional capacity to effectively curtail corrupt practices.

Corruption exists everywhere in the world but successful nations have developed strong institutions that effectively check the excesses of corrupt people. Unlike other nations, Nigeria was not born out of an agreement of people of the various ethnic nationalities that populate it; it was rather the product of an agreement between the Royal Niger Company and the British government. This unfortunate phenolmenon was captured by the Prime Minister of the First Republic, Alhaji Abubakar Tafawa Balewa 
thus: "Since 1914, the British government has been trying to make Nigeria into one country, but the Nigerian people themselves are historically different in their backgrounds, in their religious beliefs and customs and do not show any signs of willingness to unite... Nigerian unity is only a British invention" (Meredith, 2011).

Similarly, Chief Obafemi Awolowo is reported to have written in 1947 that: "Nigeria is not a nation. It is a mere geographical expression. There are no Nigerians in the same sense as there are English, Welsh or French. The word 'Nigerian' is merely a distinctive appellation to distinguish those who live within the boundaries of Nigeria and those who do not" (Meredith, 2011). Despite their realization of the situation, the founding fathers of this nation had a clear picture of the kind of country they wanted to build though it was not clear that all of them understood how they were going to do it. It is noteworthy however that the late Chief Obafemi Awolowo stands out in this regard. It was he alone among them who invested much energy into thinking out what he considered as solutions to the challenges facing the country before and after independence. His 'Path to Nigerian Free-dom' written in 1947 as well as other works reveal the depth of his passion for Nigeria and his understanding of the challenges facing the country. In his book, 'The Strategy and Tactics of the People's Republic of Nigeria', he writes:

"The economic objectives of the people's republic of Nigeria shall be as follows:

- Full employment.

- Payment of unemployment relief allowances to persons who are able and willing to Work but are unable to secure employment, during the period of their enforced idleness.

- Introduction of national minimum wage compatible with a national minimum standard of living.

- Elimination of discrimination between categories of employees; that is to say, all persons employed in the public and private sectors, whatever their categories, should be on a full-time and permanent basis, and should be entitled to pension on the same basis under a comprehensive and compulsory social insurance scheme.

- The raising of pensionable age to between 65 and 75 years, in strict regard to the types of employment.
- Modernization of agriculture as well as of the storage, transport, and marketing of farm products.

- Economics freedom; that is to say, voluntary economic independence with other Countries of the world, involving:

1) Immediate introduction of schemes for selfsufficiency in non-durable consumer goods;

2) The introduction, within five years, of schemes for self-sufficiency in durable Consumer goods; and

3) The attainment, within 20 years, at the longest, of complete self reliance in Capital goods and technical knows how.

- Modernization and the economically requisite extension, of the Nigerian railways, to ensure a greatly accelerated haulage of goods from distant parts of country to the ports.

- Construction and maintenance of adequate and modern waterways to ensure much quicker transport within and from the riverine areas of the country

- Construction of a sufficient and efficient network of all-season roads and bridges so as to attain, within 15 years, a ratio 1 mile of road to 2 square miles of territory in all part of the country

- Rationalization of the salaries and remuneration paid to, or received by different classes of employed or self-employed persons with a view to closing the existing gap between the higher and lower income groups.

- Integration and assimilation of the salaries and conditions of service of all employed persons, other than self-employed persons, with a view to ensuring. Equal pay for identical qualifications or merits in all the sectors of the countries productive activities.

This will entail the abolition of "fringe benefits" for all categories of employed persons in all sectors of the country's productive activities.

- The immediate rationalization of certain categories of industrial and commercial under-takings in order to eliminate waste arising from unnecessary duplication or multiplication of effort, selfish and cut-throat competition, and lack of coordination on the part of productive agents in given industries and enterprises.

- Immediate introduction of training schemes designed to ensure the total Nigerianization of the management and control of all productive activities in the country, within the shortest possible time. 
- Progressive and rapid socialization of the following occupation, including all services ancillary to them:

(1). Primary, manufacturing and transport occupations of defined classes, types, scales, and capacities; and

(2). Banking and insurance occupations of whatever classes, types, scales, and Capacities (Awolowo, 1970).

A cursory glance at these proposals that were written in 1969 at the Calabar Prison shows that almost all of them are still relevant today with only a few modifications. It is therefore disheartening that sixty years after Nigeria's independence, despite such lofty thoughts and postulates from one of her foremost and arguably her most outstanding politician, her performance in the spheres of social engineering, economic growth and political stability does not in any way represent her potentials, or project the true yearnings of her citizens, her vast natural endowments notwithstanding. It is therefore pertinent to move beyond the narrow concept of development to sustainable development; from mere 'growth' to 'growth plus equity' where social justice, equal opportunity and access for all classes of people are the primary focus of government. Sen for example writes: "Development connotes 'capacity expansion'.

As capacity expansion, development requires adequate empowerment of the state and the society such that they can adequately distil their complimentary responsibilities. It requires an enhanced state capacity as well as institutional and governmental stability. It is only within such frame-work that individual members of the society can find fulfilment in terms of the basic necessities of life. As freedom, development demands great latitude of autonomy for the political community and its constituent parts; as well as for the individual members of such communities" (Sen, 1990). This definition of development is comprehensive enough for economies of the past. In contemporary economics, true sustainable development should be environmentally sustainable. According to Kalyani, elements of sustainable development include:

Increase in real income per capita

* Opportunity to have a satisfying livelihood

* Improvement in health and nutritional status

* Improvement in Educational status

* A fairer distribution of income
* Assurance of basic human rights

* Conservation of nature and resources (Kalyani, 2004).

In light of the above, the average Nigerian is not interested in the name we choose to call a system of government. A benevolent autocratic system will appear preferable to him as long as he experiences social justice and sustainable development while a democracy will always be repugnant to him as long as he does not see any improvement in his wellbeing. He believes that the nightmares caused by insurgents, kidnappers, bandits and terrorists are byproducts of social injustice that has become the main theme of the Nigerian socio-political trajectory. In Nigeria today, as in other under-developed or developing nations, wrong diagnosis of the cause or causes of poverty has prevented the policy makers from developing the necessary capacities for eradicating it. It is often thought that overpopulation is the cause of poverty and much energy and resources are dissipated on issues of birth control and family planning. But the truth of the matter is that poverty is majorly caused by overconsumption and seldom by overpopulation. Over consumption depletes nonrenewable resources like metals and minerals. It also depletes and degrades renewable resources through practices such as overfishing, overhunting and overexploitation of forests and groundwater. It also creates pollution and waste that go beyond the capacity of the environment to absorb. At the individual level, overconsumption reflects in our basic means of existence. The amount and kind of food we eat, for instance, determines whether we are meeting our basic needs or over consuming. Taking cassava dough with vegetable and fish or meat is basic, but taking it with vegetable, fresh fish, bush meat, goat meat and assorted meat at the same time in the same sitting is overconsumption. Akin to this is the insanity Nigerians display in their love for automobiles. It is understandable if a middle class family has two or three cars, but in a situation where-by an individual owns 10,20 or even 30 cars can only be described by one word-crazy! Reacting to the report of some public office holders keeping stolen money in septic tanks, one religious leader has proposed that rather than sentencing such people to prison, they should be sentenced two years in the psychiatric home (Alatoye, 2014). Surely, God has created enough to meet human needs but He did not create enough to service human greed. Over-population is 
often seen as being caused by high birth rate which itself is most often a product of a psycho-social response of the people to their economic challenges. They tend to have more children when:

- health facilities are inadequate and life expectancy is low, people are not sure how many of their children will survive into adulthood.

- Women do not have easy access to good education and paid employment.

- When people do not have access to social security and pensions and they feel they need many children to support them in old age (Kalyani, 2004).

The problem is therefore not the population but the absence of people-friendly government policies supported by lofty ethical values. Over population is often erroneously measured in terms of numbers and this is highly misleading. An area is overpopulated when its population cannot be maintained without rapidly depleting natural resources and without degrading the capacity of the environment to support it. Every area on earth has a carrying capacity which is the maximum number of people it can support. The carrying capacity can, to some extent, be increased with technology but not indefinitely. Today, many nations have enough space to carry their population but they have given richer nations easy access to their resources and their environments start to lose the capacity to support the population as if they are overpopulated. Government policy, and not overpopulation, is the culprit in such societies.

\section{CONCLUSION:}

In light of the foregoing, Nigeria's democratic trajectory and development drive depend largely on quality of governance. Its adventure since its independence in 1960 has belied the hopes and dreams of its citizens despite the multiplicity of nature's gifts it enjoys due to the poor quality of governance offered by successive regimes. This has led to the unfortunate phenomenon of brain drain which is sustained in a continuum- a situation that has attracted multi-sectoral condemnations and censures such that Arabic verse-smiths who had hitherto been passive in socio-political discourse, as evidenced in the poem studied, were drawn into the fray.In order to redeem and reposition its corporate image, the nation needs to tackle the challenge of insecurity by entrenching social justice in its social universe as well as cure the maladies of political corruption and over-consumption if it must attain sustainable development. To do this, there is a dire need for a total reorientation of the masses through a consciously planned, purpose driven ethical revolution and faithfully implemented interventions that would be multi-sectoral, multifaceted and multi-dimensional.

\section{ACKNOWLEDGEMENT:}

I acknowledge the direct and indirect contributions of all the authors whose works are cited in this article as well as scholars and students with whom I have discussed aspects of the topic in class or at conference tables.

\section{CONFLICTS OF INTEREST:}

I hereby affirm that there is no competing interest involved in the work hence, no conflict is anticipated.

\section{REFERENCES:}

1) Achumba et al. (2013). 'Security Challenges in Nigeriaand the Implications for Business Activities and Sustainable Development', J. of Economics and Sustainable Development, 1(2), pp. 85.

https://core.ac.uk/download/pdf/234645825.pdf

2) Alam S, Mukta SY, Iqbal $F$, and Sarker $T$. (2021). Statelessness in south asia: present scenario, violation of human rights, grounds and redresses, Asian J. Soc. Sci. Leg. Stud., 3(3), 99-106.

https://doi.org/10.34104/ajssls.021.0990106

3) Alatoye, A. A. (2014). 'Islam and Good Governance' paper presented at the Annual Conference of the Ahmadiyya Muslim Jama'at, Nigeria, and December 26-28, 2014.

4) Alina, R. M. (2007). 'Analysing the relationship between Democracy and Development: Defining Basic concepts and Assessing key linkages', paper presented at the Wilton Park Conference of Democracy \& Development, October 22-25, 2007.

5) Awolowo O. (1970). 'The Strategy and Tactics of the People's Republic of Nigeria, Tribune Press, Ibadan, Nigeria.

https://tribuneonlineng.com/strategy-tactics-peop les-republic-nigeria-economic-objectives-i-5/

6) Dabak P. D. (2014). 'Insecurity and the Challenges of Development in Nigeria', Developing Country Studies, 4(22).

https://issuu.com/alexanderdecker/docs/insecurit y_and_the_challenges_of_de 
7) Epperson A. R. (1985). The Unseen Hand: An Introduction to the Conspiratorial Views of History, The Publius Press, Arizona

https://www.abebooks.com/book-search/title/uns een-hand-introduction-conspiratorial-view/autho r/ralph-epperson/

8) Fresia, J. (1998). Toward an American Revolution, South Ene Press, Boston.

https://www.biblio.com/toward-an-american-rev olution-by-fresia-jerry/work/1139195

9) Jamo I. A. (2013). 'Democracy and Development in Nigeria: Is there a Link?'Arabian J. of Business and Management Review, 3(3), p.87. https://www.arabianjbmr.com/pdfs/OM_VOL_3 _(3)/11.pdf

10) Kalyani K. (2004). 'Population, Consumption and Environment' in K. Chokar, M. Pandya, M. Raghunathan (eds), Understanding Environment, Center for Environment Education, Sage Publication, New Delhi, pp. 263 - 265.

11) Majekodunmi, A. (2012). 'Democratization and Development in Nigeria: The Fourth Republic in Perspective', in International $J$. of Academic Research in Economics and Management Sciences, 1(5), p. 63. https://ssrn.com/abstract=2637159
12) Meredith Martin, (2011). The State of Africa, Simon and Schuster, United Kingdom https://www.amazon.com/State-Africa-Continent -Independence-Meredith/dp/0857203886

13) Rummel R. J. (1977). 'Frustration, Deprivation, Aggression, and The Conflict Helix' in Understanding Conflict and War, 3(3). https://doi.org/10.2307/1955033

14) Salawu B. (2010). 'Ethno-Religious Conflicts in Nigeria: Causal Analysis and Proposals for New Management Strategies', European J. of Social Sciences, 13(3), p. 345. https://doi.org/10.12691/education-3-3-7

15) Sen, A.K. (1990). 'Development as Capacity Expansion' in K. Griffing, and J. Knight (eds), Human Development \& the International Development Strategy for the 1990s, London, pp. 41-58.

https://scholar.harvard.edu/sen/publications/deve lopment-capability-expansion

16) Stewart F. (2004). 'Development and Security', Working Papers 3 of the Centre for Research on Inequality and Human Security, University of Oxford, $\mathrm{p} 2$.

https://www.gov.uk/research-for-development-o utputs/development-and-security

Citation: Timehin SO. (2021). A toddler at 60? Nigerian's democracy and development under Arabic poetic loupe, Br. J. Arts Humanit., 3(6), 149-158. https://doi.org/10.34104/bjah.02101490158@ @ @ 